\title{
OLD AGE IN THE BRAZILIAN BUSINESS PRESS: NEW CULTURAL SENSIBILITIES IN A FINANCIALIZED ECONOMY
}

\author{
A velhice na imprensa de negócios: novas sensibilidades culturais \\ em uma economia financeirizada
}

Fernanda Veríssimo Soulé*

\begin{abstract}
The financialization of the economy has been extensively studied in economic and organizational sociology. This literature focuses on changes in organizations associated to the shareholder value culture and on how financialization influences several domains of life. Based on the literature from this broad scope of social impacts of financialization and on sociological approaches to old age, this paper analyzes the predominant conceptions of old age diffused by the Brazilian business press in the context of increasing longevity of the population and their relation with the emergence of the financialized economy in Brazil. To address the issue, we carried out a content analysis of the 636 issues of Exame, the main Brazilian business magazine, comprising the period from 1990 to 2014 . A corpus of 230 articles was then selected and systematically assessed. The results were analyzed combining ideas from the Reflexive Sociology of Bourdieu and the Pragmatic Sociology of Boltanski. Four ideas or aspects prevailed in the material assessed: i.) planning for retirement; ii.) rationalized life and financial approach to old age; iii.) population aging and its micro and macroeconomic impacts, and; iv.) generational demarcation and disputes in organizations. Economic logic was dominant, reflecting in more or less explicit proposals of a financial model to frame life.
\end{abstract}

Keywords: Old Age. Retirement. Financialization of Everyday Life. Business Media. Content Analysis.

\section{RESUMO}

A financeirização da economia tem sido extensivamente estudada nas sociologias econômica e das organizações. Essa literatura analisa tanto as mudanças nas organizações associadas à cultura do valor ao acionista, quanto a forma com que a financeirização influencia diversos espaços da vida cotidiana. Com base na literatura relacionada a esse escopo mais amplo dos impactos sociais da financeirização e nas abordagens sociológicas à velhice, esse artigo analisou as concepções de velhice difundidas pela imprensa brasileira de negócios no contexto do aumento da longevidade da população e da emergência da financeirização da economia em nosso país. Para isso, foi realizada uma análise de conteúdo de 636 edições, publicadas entre 1990 e 2014, da Revista Exame, a partir das quais foi selecionado um corpus de 230 matérias que foi sistematicamente analisado. Os resultados foram analisados combinando ideias da Sociologia Reflexiva de Bourdieu e da Sociologia Pragmática de Boltanski. Quatro noções prevaleceram no material avaliado: i.) Planejamento da aposentadoria; ii.) Vida racionalizada e uma abordagem financeira à velhice; iii.) Envelhecimento da população e seus impactos micro e macroeconômicos, e; iv.) Demarcação e disputas geracionais nas organizações. A lógica econômica foi dominante, refletindo em propostas mais ou menos explícitas de um modelo financeiro para enquadrar a vida.

Palavras-chave: Velhice. Aposentadoria. Financeirização da Vida Cotidiana. Mídia de Negócios. Análise de Conteúdo.

* Doctoral candidate at the Production Engineering Graduation Program at Federal University of São Carlos (UFSCar), with an integrated research period ("sandwich model") at the Stanford University. Researcher at the Núcleo de Estudos em Sociologia Econômica e das Finanças (NESEFi) from the Federal University of São Carlos (UFSCar) - São Carlos (SP), Brasil. E-mail: fernanda.soule@gmail.com. ORCID: 0000-0003-1385-1069 


\section{INTRODUCTION}

$\mathrm{T}$

he financialization process of the economy has been extensively studied in economic and organizational sociology. Davis and Kim (2015) show that this literature focuses on changes in organizations associated to the shareholder value culture and on how financialization influences the broader society, being a pervasive phenomenon, influencing not only the dynamics of the economy, but several domains of life.

In line with this broad scope of the social impacts of financialization, this study analyzes the predominant conceptions of old age diffused by the Brazilian business press in the context of the increasing longevity of the population and the relationship of these conceptions with the emergence of the financialized economy in Brazil. I draw on the notion that interpretations of old age and generations are socially constructed (MANNHEIM, 1928), instead of being merely related to numbers or biological stages (ARIÈS, 1978). The focus is to understand the interrelation between the meanings of old age and the emergence and transformation of markets and the influence of the financialization of the economy in these meanings. While the view that the elderly are a burden, generating expenses for the State and being dependent on others is still dominant, over the last decades those with greater economic resources have increasingly received attention from market actors, in what is being called the aging economy (MEINERS, 2014) and grey/silver market/economy (KOHLBACHER; HERSTATT, 2011). As a result, the hypothesis of an economic catastrophe associated with demographic changes currently shares space with a view of the elderly as a potential source of economic growth and of new job markets (MURATA, 2011; CLARK, KREPS; SPENGLER, 1978).

Assuming that, journalists and editors are representatives of a middle-class morality (BOURDIEU, 1996), operating as an echo chamber (JAMIESON; CAPPELLA, 2008), the meanings of old age and the elderly were addressed by means of the business press content. Mass journalism is part of the large-scale production (BOURDIEU; JOHNSON, 1993; WACQUANT, 2005), so it is dependent on demand and is, therefore, a heteronomous field liable to pressures of the economic field. To meet the metrics of the field, the categories of journalists must adjust to their target audience, so that the content they produce is an exemplar of the more widely accepted conceptions.

Besides, dominant media production is generally carried out by professionals with relatively high economic and cultural capital, exercising several forms of symbolic violence, imposing their beliefs and representations of reality in the content they produce (BOURDIEU, 1987; CHAMPAGNE, 2000). Their articles are symbolic goods that have broad effects on society but also specific effects on the economic order (BOURDIEU, 1997). The production of such symbolic goods takes place through a process which is not necessarily intended or rational, but built from the cognitive models of journalists. Therefore, the diffusion of categories in the media is subjected to these cognitive structures or principles of vision and division of the social world (BOURDIEU, 1998). Thus, the positions taken by media actors are related to the space they occupy in the field and the relationship of that space with other fields. 
Business media has a special role in the propagation of new categories to economic actors. The spread of these new categories will depend on the alignment between them and the audiences' views. Market actors translate new categories to their specific contexts, which also occurs by means of the information provided by the media. For example, the elderly category was created by the State and appropriated and widespread by the media, among other actors, which highlights some aspects and ignores others. Aspects highlighted are often related to preconceived notions and also previously accepted by the audience. On the other hand, a sense of opportunity for economic actors in relation to this new category may also generate a new understanding of these phenomena in the media, mobilizing displacements in their discourses.

Furthermore, since the economic space is intertwined with the social one, studying the conceptions diffused by the business press is relevant to understand the social space as a whole, not only the economic field. The methodological approach of assessing business press articles related to old age is based on this notion of the economic field as pervasive and gives us insights into what conceptions have been influencing this aspect of life of ordinary individuals.

The first section presents the theoretical background, detailing the approach to old age in which I draw on and the phenomenon that has been called financialization of everyday life. Then, the methodological approach and the content analysis research techniques are described. In the third section, results and discussions, there is an assessment of the target audience and of the journalists who produced the articles being assessed. Then, the content analysis is presented, with some of the quantitative data gathered, a qualitative analysis and the categories found. Finally, the last session concludes the article with the final remarks, in which the influence of finance in such a particular aspect of life, as old age, is reiterated.

\section{THEORETICAL BACKGROUND}

This section draws on two literatures. First, we present some important references about old age. In doing so, we intend to sensitize our reader to the notion of old age as socially built subjectivities instead of a purely biological stage (ARIĖS, 1978). Second, we discuss what has been called the financialization of everyday (or daily) life and how this paper connects to that literature.

\subsection{OLD AGE AS A SOCIAL PHENOMENON}

In this subsection, I discuss how interpretations of old age influence the emergence and transformation of markets departing from the literature on the sociology of aging and analyzing the idea of gray/silver economy. Although aging is a biological process, the meanings of old age should not be considered a natural data. As authors such as Halbwachs (1944) and Mannheim (1928) show, these meanings are social constructions based on historical experience and relationships and are related to time, customs, institutions and population or group composition. 
Molls (1959) states that the genesis of age classification is associated to the fourteenth century and is related to the need of separating productive and non-productive people. Age classification as we know it today is only possible with birth registration, since age represents the lifetime after birth. Silveira and Laurenti (1973) demonstrate that forms of birth registration have existed since Antiquity, but it was in the fifteenth century in Europe, with the parochial records of the Catholic Church, that this practice was systematized and strengthened.

Lenoir (1999) demonstrates that the idea of old age as a social problem started being diffused in the 19th century, which, according to Dumons and Pollet (1994), is related to the advent of capitalism, in which old age is associated with the inability to produce. In this sense, authors such as Trempé (1971) and Macnicol (2015) show that retirement was created so that the elderly could be withdrawn from their jobs, based on the idea that the cost of their labor was too high concerning their productivity, considered lower than the younger adults. This indicates that the idea of retirement, since its very beginning, has produced significant changes in the social status occupied by people in society, with the elderly being seen as less productive. Furthermore, the emergence of old age as a social problem also helped to spread a notion of intergenerational disputes for State resources (GOLDANI, 2004). with old age-related policies being considered as competing for resources that could be destinated to investments for younger generations, such as education and childcare.

Aiming to break with this view and to promote improvement in the quality of life and increasing longevity for old people, several organizations around the world have endorsed other notions of old age. In the 1970s, a concept that is called productive aging began to spread. In the late 1990s, the World Health Organization (WHO) focused on disseminating the conception of active aging towards a notion of active that goes beyond physical and labor issues, being related to the participation in social, economic, cultural, spiritual and civic affairs (WHO, 2002, p. 12). At the Second World Assembly on Ageing, promoted by the UN in 2002, these aspects were also included in the concept of old age, generating an international plan for the training of individuals over 60 for paid and voluntary work.

It is worth noting that the idea of working or staying productive as something that increases life expectancy or contributes to a healthy aging process is associated to a specific social space, as highlighted by Pellissier (2013, p. 2): the work retains [...] those it did not kill. This is made clear by comparing the life expectancy of some countries according to their so-called level of development. In its annual statistics report for 2014, WHO showed that the life expectancy, in 2012, of a male in high-income countries was 76 years old, while in low-income countries it was 60 years old (WHO, 2014) The notion of the elderly also varies according to the socio-professional category, since, for example, manual and office workers have different life expectancies, as presented by Blanpain (2011)1.

Besides the problems pointed out above related to the emergence of the elderly category, such as the promotion of a notion of intergenerational dispute for resources and the difficulty to, sometimes, consider the plurality of this aspect of life, categorization is essential

1. Blanpain (2011) presents a table with the expectation of years to live for 35-year old individuals by sex and social category in the French society from 2000 to 2008 . The social categories listed by her, from higher to lower life expectation, are Managers, Intermediate professionals, Peasants, Artisans, traders and CEOs, Employees, Workers and inactive non-retired people. 
in the development of public policies that meet the specificities of a particular social group (CAMARANO; PASINATO, 2004). To be able to respond to demands related to older individuals, the State created a category that encompasses them and defined who belongs to it. In a broader way, age groups are established by the State, defining the time to enter school, to work and to retire, that is, the ages defining the social roles of individuals, which depends on the relations of force between generations (MAUGER, 2013). In this sense, the State created the elderly category and defined age as a way of separating the elderly from the non-elderly.

For the State, it is fundamental to be pragmatic in the form of categorizing individuals, which in general tends to simplify the heterogeneity of such categories (CAMARANO; PASINATO, 2004). This is because, when a category is created, it also promotes expectations regarding the behavior of people belonging to that group, and society starts to exercise various forms of symbolic violence (BOURDIEU, 1985) so that the expected social role is practiced, tending to disregard the particularities of individuals (LASLETT, 1987).

States are not alone in the creation and diffusion of the old age category. There are other actors who are also key in this process, such as academia, health care, demography and multilateral organizations, as the above-mentioned endeavors from WHO and the UN. However, what is especially relevant to this paper is the role of media in the process of ascribing meaning to old age and aging. In Brazil, several studies already point to this.

Debert (1997) depicts the role of the media in promoting the idea of old age as an individual responsibility and in endorsing a consumption market related to aging or, rather, to products and lifestyles that allow people to keep young. Mascaro (1993) and Neri (2006) assessed the Brazilian newspaper $O$ Estado de São Paulo and were mainly worried about the meanings given to old age in that newspaper. They considered different periods, with Mascaro (1993) analyzing publications between 1988 and 1991, and Neri (2006), between 1995 and 2002. In his Master thesis, Pires (1998) analyzed how old age was presented for each gender comparing two magazines: Claudia, whose target audience is women, and Playboy, which is male-oriented. From some international and national empirical research about the elderly in advertising, Leite (2002) points to the mainly negative representations of old age in the media and to how, over the $20^{\text {th }}$ century, it has changed from an almost purely negative view to an understanding of older people as a potential consumption market. Debert (2003) also assessed the elderly in advertisements, showing the role of those in producing what the author calls reprivatization of aging, which is related to the individual capacity of avoiding old age.

There are also international studies which depict the impacts of the media in the imaginary of old age. Greenberg, Korzenny and Atkin (1979) compared samples of network fictional television series in the United States in three years (1975, 1976 and 1977), assessing the social profiles and behaviors performed by the older characters. Bell (1992) also assessed television programs, specifically the images of aging in five prime-time programs mostly watched by the elderly in 1989 and which had key elderly characters. Gadson (2003) identified the major themes and meaning systems of two US newspapers related to elderly care responsibility. Clark, Bennett and Liu (2014) analyzed the portrayals of aging in advertisements and interest stories in six widely read male-oriented magazines in the USA. Brown and Knight (2015) assessed advertisements for beauty products from 1960 to 2010 in two of the main Australian magazines whose target audience are women. 
Markets influence and are influenced by these processes in a variety of ways. The creation of a Third Age Consumer Price Index (Índice de Preços do Consumidor da $3^{a}$ Idade - IPC-3i) exemplifies the notion that the elderly have different consumption needs in relation to the individual considered in the traditional Consumer Price Index. For Leibing (2005), the notion of third age was created and diffused as a movement to demystify aging as something purely negative or decadent. Debert (1997) states that, in a way, there is a search for reconceptualizing the idea of old age, moving away from the notion of old age as a source of misery towards a view of old age as a source of resources, which is mainly due to the fact that the lifestyle of the elderly is getting more similar to the lifestyle of non-elderly adults, who are considered productive.

If, on the one hand, the elderly are considered a burden, generating expenses for the State and being dependent on others to be cared for, on the other hand, those with greater resources are increasingly receiving the attention of the markets in what is being called the economy of aging and the silver market. In this sense, the idea of economic catastrophe associated with demographic changes currently shares space with the notion of potential and opportunities associated with the aging population, which is considered a possible source of economic growth (MEINERS, 2014; MURATA, 2011; TEMPEST; BARNATT; COUPLAND, 2011) and new labor markets (MURATA, 2011; CLARK; KREPS; SPENGLER, 1978; KOHLBACHER; HERSTATT, 2011).

Both as a business opportunity and for the job market, old age is not a homogenous category, and the space the elderly occupy is directly related (but not just) to their economic capital. Besides the creation of what Debert (1997) points out as a proliferation of intermediate stages of aging, as is the notion of third age, which promotes certain specific segments of the elderly to a relevant consumer category, older people from lower classes remain socially excluded from the markets, and their demands and realities continue to be generally unknown. If markets are a way to socially include the elderly from higher social classes, they also help to reproduce various forms of exclusion and prejudice, as observed by Williamson (2001) in the case of private pension schemes in Latin America, which raised the income and gender inequalities among retirees.

\subsection{FINANCIALIZATION OF EVERYDAY LIFE}

Authors from Economic Sociology have been using the idea of financialization to discuss the changes occurred in capitalism within the last decades, which consists of a transition from industrial capitalism to finance capitalism (FLIGSTEIN, 1993; DAVIS, 2009). Davis and Kim (2015) claim financialization is related to the domination of finance over other aspects of economy, which also means a cultural domination of many areas of life. Van de Zwan (2014, p. 101), in her state-of-the-art paper toward financialization, states that

Finance capitalism or financial capitalism, then, denotes a form of capitalism, in which finance has become the dominant function in the economy and has extended its influence to other areas of life (e.g. social and political). Financialization refers to the web of interrelated processes - economic, political, social, technological, cultural etc. - through which finance has extended its influence beyond the market. 
In the introductory chapter of his book, Martin (2002) shows how newspapers and television have presented finance as something fun, easy and as part of the daily life of every single individual. Besides, he discusses how financialization is supported not just by the media, but also by the State, once it affects the demands and expectations of the citizens regarding official policies. Along these lines, Carruthers and Kim (2011) state that financial markets always work in a political context, therefore politics have an important role in the process of financialization, for example, with the deregulation of the financial sector during the 1980s and 1990s in many countries.

These changes have raised the interest of many scholars in the subject. Van der Zwan (2014) shows there is research which focuses on the macro, meso and micro level aspects of financialization or on combinations of them. The former (e.g.: CARRUTHERS; KIM, 2011; DAVIS; KIM, 2015; KRIPPNER, 2005) are mostly worried about the expansion of global financial markets. Studies such as Fligstein and Shin's (2007) and Davis's (2013), which mainly analyze the meso level issues, are primarily studying the phenomenon of shareholder value. The latter deal with non-elite actors, i.e., the impact of financialization in the lives of ordinary citizens, which is also the contribution of this paper.

Some studies have shown the influence of finance in the everyday life (MARTIN, 2002; DAVIS; KIM, 2015; VAN DER ZWAN; 2014; LEBARON, 2010). Erturk et al (2007) demonstrate that finance became a part of daily life by means of a process of democratization of finance, which allowed a broader part of the population to access financial products and services, rather than restrict them just to the rentier elites. These and other authors discuss how this process of citizens participating in financial markets creates a new subjectivity, encouraging them to economically structure domestic life and promoting the incorporation of a risk-taking logic. Martin (2002, p. 3) points out that finance merges business and domestic life cycles and has been proposed to acquire a self, and money has become both the means and end of life. Moreover, he says that the recent concept of personal finance diverges from the one of the mid-20th century, when the idea of saving used to prevail. For him, in this new model, money is seen as something to be constantly handled and employment is not supposed to be the only source of it. Common citizens, from lower and middle classes, are told to strategically invest their money. Therefore, in the words of Martin (2002, p. 12), without significant capital, people are being asked to think like capitalists.

Davis and Kim (2015) also discuss the impact of financialization on the everyday life and subjectivities of individuals. They present the following very interesting notions.

[...] Financialization extends to the everyday life of ordinary people, as participation in finance arguably reshapes the way people think about their lives and the world around them. Financialization underwrites narratives and discourses that emphasize individual responsibility, risk-taking, and the calculative nature of financial management (MARTIN, 2002). Our physical environment is filled with pervasive images and texts of financialization, such as "advertising campaigns, money magazines, investment manuals and financial literacy campaigns" (VAN DER ZWAN, 2014, p. 112). This prevalent "finance culture" creates an image of the individual as an "investing subject" (AITKEN, 2007, p. 13), who "insures himself against the risks of the life cycle through financial literacy and self-discipline" (VAN DER ZWAN, 2014, p. 113). For the investing subject, the uncertainty of the future is not something to be 
feared but to be embraced, because financial theory posits that only those who bear risks can achieve investment returns. Moving away from the security provided by the postwar welfare schemes, ordinary American citizens are told to embrace such instability as an opportunity to bear risk and be successful in the "ownership society" (DAVIS, 2010; DAVIS; KIM, 2015, p. 10).

This paper aims to contribute to the discussion about the financialization of daily life, investigating if and how this world model (GRÜN, 1999) related to the financialized economy transformed the prevalent conceptions of old age in the Brazilian society.

\section{METHOD}

The present study is an exploratory research focusing on the relations between the meanings of old age and the economic field. Its approach is predominantly qualitative, since the analysis of the phenomenon in question considers the different perspectives of the actors involved (FLICK, 2004), and the type of research is theory extension or refinement (VOSS; TSIKRIKTIS; FROHLICH, 2002), aiming to contribute to a better structuring of existing theories in light of empirical data. Simple quantitative tools were applied, such as absolute and relative descriptions of the themes identified, aiming to better understand their magnitude in the articles analyzed.

The analysis of cultural sensibilities about old age was based on the content of Exame, the main Brazilian magazine for business executives, according to circulation indexes (INSTITUTO VERIFICADOR DE CIRCULAÇÃO, 2014; MIDIA COMPANY, 2013). Assessing this content in a mass media magazine is pertinent because large-scale journalism is subsumed to the economic field pressures and is also an important disseminator of economic categories, exerting pressure on several subfields (BOURDIEU; JOHNSON, 1993; WACQUANT, 2005).

The source of data were the 636 editions of Exame magazine published between 1990 and $2014^{2}$, which cover the period of the creation of the main Brazilian ordinary laws for the protection of the elderly ${ }^{3}$ and of the process of financialization of the Brazilian economy, which was opened in the 1990s. Data were collected in Hemerotheca Mario de Andrade, located in São Paulo, SP, Brazil ${ }^{4}$. Access to the physical magazines allowed a broader view of the context of each publication.

he analysis technique was based on Bardin (1979) and Bourdieu (1977). A categorical thematic content analysis was performed, with the addition of elements from the evaluation analysis (BARDIN, 1979). First, based on the theoretical framework, a Microsoft Excel spreadsheet was designed for data collection and processing, which was improved after the free-floating reading of some articles. The instrument was designed to systematically extract the following information: focus of the article; article's general topic; direction of the

2. Except for editions $1055,1058,1061,1062,1079$ and 1080, which were not available.

3. The Elderly National Policy and the Elderly Statute were created in 1994 and 2003, respectively.

4. Exame is not fully available in digital sources. 
message (old age as positive, negative, neutral or ambivalent); elderly conception; attitude objects ${ }^{5}$; terms associated with markets; organizations mentioned; people mentioned; countries mentioned; authorship. Then, the articles related to the topic of research were selected (PINTO; GRAWITZ, 1969). The selection criterion for the composition of the corpus of the content analysis was the presence of terms related to the elderly or old age. All articles containing them were read in full and their data was collected using the spreadsheet.

The results were analyzed using the Reflexive Sociology of Bourdieu, adopting a permanently reflexive posture regarding the empirical findings and using the theory as a way to mediate the understanding of particular situations (BOURDIEU; WACQUANT, 1992). According to these authors, theory and method are inseparable and theory is a relational theoretical tool that guides the analysis and interpretation of the data. The analysis also drew from the Pragmatic Sociology of Boltanski, especially Boltanski and Thévenot (2006), to understand how the moralities enacted in modern society appear in the arguments assessed.

\section{RESULTS AND DISCUSSIONS}

Drawing on the notion stated by Beauvoir (1970) that general pleas about old age must be refused, the first subsection specifies the elderly as represented by Exame magazine, which reverberates the patterns of the elderly and old age related to its target audience and journalists. The second subsection presents the data gathered in the 230 articles of the corpus of the content analysis. The last subsection presents the four major categories found. All of them are, in varying degrees, are influenced by ideas related to financialization, especially by means of pension funds and schemes. Propositions about each category are presented, considering their potential influences in the daily life of individuals, organizations, economics and the Brazilian society in a broader way.

\section{I WHO ARE THE ELDERLY WE ASSESSED?}

Since different social groups have different expectations and views about old age, it is important to frame how old age is represented by Exame. First, it is worth assessing the reader profile and the displacements in it during the period under review, to be aware of whom Exame wanted to sensitize with the notions of elderly it promoted. A market survey about Exame subscribers, conducted in 1990, described its target audience as being formed mainly by young men of the upper classes (EXAME, 1990). In the following years, the participation of readers from 50 to 60 years old and, especially, women had significantly increased (IPSOS MARPLAN, 2007). There was a smaller change in relation to their income. The same research pointed out that $91 \%$ of directors and presidents of the largest 500 Brazilian companies read Exame and, in 2013, another survey showed that 35\% of the subscribers were CEOs or business owners (MÍDIA COMPANY, 2013), indicating a close relationship between the publication and these elites. However, somehow, readers previously marginalized, such as women, individuals from the so called middle-aged and middle class

5. This term is used by Bardin (1979) to refer to the words and terms that are being evaluated or classified by the content producer. 
gained relevance, which may be related to the increase of their power consumption and interest in topics covered by Exame.

Although there was this shift in the reader profile, the presence of women and the elderly in the magazine's media materials was almost inexistent, as can be seen in the media kit presented by Mídia Company (2013). All the media kits assessed (EXAME, 1990; IPSOS MARPLAN, 2007; MÍDIA COMPANY, 2013) highlight the same average reader: the white male from economic elites, representative of the traditional family model and who belongs to economic spaces considered globalized and professionalized, such as multinationals and banks.

Moreover, the profile of their journalists, editorial teams and their main references are important so as to understand who is setting the agenda. Thus, the main aspects of the academic background and practical experience of the most frequent authors of the articles that belong to the corpus of this study were raised. There were nine authors that published almost $30 \%$ of the articles analyzed $(65 \text { articles })^{6}$ and their main feature is a strong background in finance and economics, present for almost all of them.

The alignment between the articles' themes and the authors' backgrounds might be explained by their competence. However, it is also worth noting that the promotion of conceptions of old age in line with the authors' backgrounds is key to maintaining their domination in the field, once it would promote them as key actors in such social space.

\subsection{THE THEMATIC AND EVALUATION CONTENT ANALYSIS}

The data collected and assessed are related to issues 444 to $1080^{7}$, published from 1990 to 2014. Among the issues consulted, there were 428 which did not have publications that were the focus of this study and there were issues that presented more than one publication of interest, resulting in a corpus of 230 articles. There was a reference in the cover of the magazine for 41 of these articles, which represents $18 \%$ of the total. Figure 1 presents the number of publications of the main general topics per year. These topics are: retirement; consumption/new markets or products specialized in the elderly or in preventing aging; investments for retirement; State pension fund; pension schemes and pension funds; job and work. Each of them appeared at least in ten articles and their total represents more than $60 \%$ of the corpus. The black line shows the total per year and is a reference to see the impact of these recurring topics in the total of the corpus.

The largest number of publications occurred from 1995 to 1998 (77 publications), representing almost 35\% of the total. This may be related to the magazine's position on the privatization of the pension system, which was being discussed by the federal government ${ }^{8}$.

6. The authors' background was raised only for the ones who had more than two articles assessed. About $20 \%$ of the articles (50 articles) were of unknown authorship and the remaining 50\% (132 articles) were distributed between 98 authors.

7. Except for issues 1055, 1058, 1061, 1062, 1079 and 1080, that were not found.

8. Between 2005 and 2006, the magazine also advocated the urgency of the pension system reform. Most of these articles were analyzed in a more qualitative way, since they did not present terms associated to old age or retirement, and therefore are not represented in Figure 1. 
We might also relate this peak of publications to the creation of the $\mathrm{PNI}^{9}$ in 1994 , but actually, there was not any article even mentioning this law.

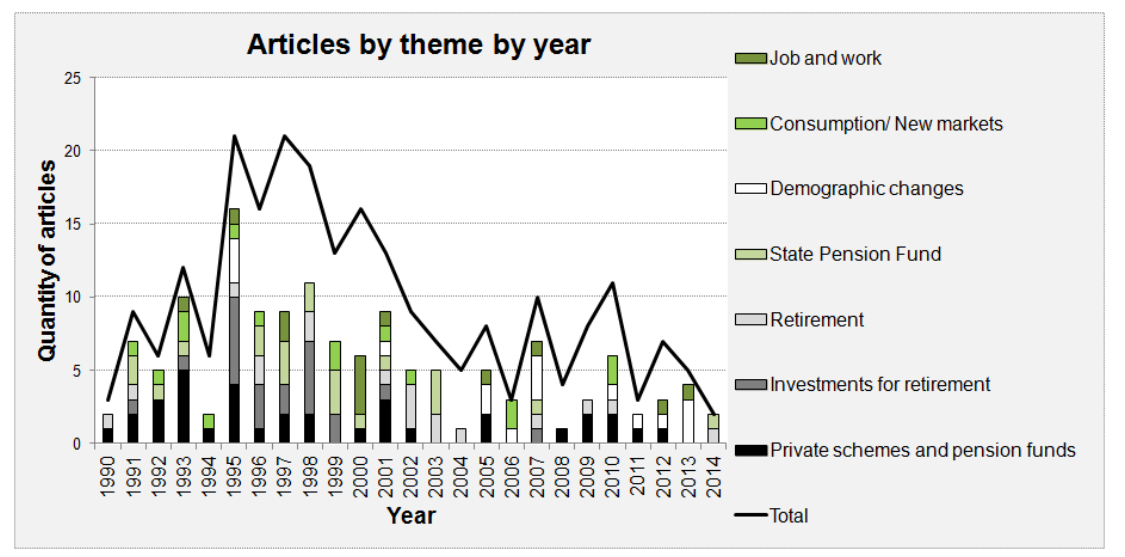

Figure 1 - Quantity of articles assessed by the main topics and in total per year.

Source: Elaborated by the author.

Yet, there were publications that indirectly touched the issue of old age, but only their key messages were assessed. In 1990, they were mainly associated with retirement of top business executives, the generational succession in large companies and inheritance. In 1990, these issues used to be presented as an intergenerational dispute and a fear of retirement. In 1991 and 1992, the decrease in the average age of corporate executives was insistently presented, mainly being associated to the idea of companies seeking more energy, new knowledge and better results. From that period on, there was an increase in the number of publications related to retirement and pension plans and funds. At the same time, there was an expansion in the diversity of themes related to old age presented in the magazine, but with a focus on issues associated with finance, on a personal level, and labor market. These themes were used as a backdrop for promoting the private pension schemes and, from 2007 on, also for other financial investments.

Regarding the attitude objects (BARDIN, 1979), they were classified into 20 topics. Consistent with what was found in relation to the general themes of the publications, the attitude objects associated with the topic of retirement are greatly represented in the assessed articles and can be found in almost $70 \%$ of them.

Data about markets mentioned in the publications were also compiled. Those associated with retirement had the highest turnout, as was expected. Both the private pension markets and the State pension fund were found in the articles focusing on the issue of retirement. It is worth noting that the two topics related to markets with the greatest presence in the assessed publications were retirement and finances, topics directly linked to the financial market, which gained significant attention in Brazil during the period. The markets that were not strictly financial and that were more recurrent were leisure, healthcare and labor.

Yet, we took note of the individuals and organizations mentioned. There were 589 individuals cited, with 70 of them appearing more than once and 19 more than twice. We

9. Política Nacional do Idoso (PNI) is the Brazilian National Policy of the Elderly. 
analyzed the background of eight of them, which were mentioned at least four times. Five of them are directly related to finance, mainly through private pension funds, one is related to public finances and the other two are the former presidents Fernando Henrique Cardoso and Luiz Inácio Lula da Silva.

The organization which was most commonly mentioned was INSS ${ }^{10}$, cited in several articles discussing the issue of financially planning for retirement and which promoted the idea that pension provided by the INSS was not enough for the individual's maintenance. The second most cited organization was the pension fund, which was proposed as a way to increase retirement income. Individually the pension funds are cited less often than the INSS, once the entities mentioned varied, but if they are considered together, their presence was higher. In addition to the private pension funds themselves, there were associations and regulatory agencies related to them. There was still a great presence of banks, which are also referred to alternately in the articles. Moreover, IBGE ${ }^{11}$ and Harvard University were frequently cited to reinforce arguments related to the aging population.

Regarding the countries that were most commonly mentioned, Brazil is cited in $40 \%$ of the publications and the United States in 31\%. The USA was mentioned considerably when journalists compared the personal financial investment habits of its population, taken as a reference for Exame, and the Brazilian's, presented as far from desired. Other countries that were recurrent in the publications are Japan, Germany and France, used comparatively to Brazil in relation to the aging process of their populations and to pension system models. The aim was to present the idea that these developed countries had a slower population aging process and had gone through what some demographers call demographic bonus. On the other hand, the so-called developing countries such as Brazil were experiencing an accelerated process of population aging, with a short period of demographic bonus, and should use this moment they were going through to improve their economy. The articles argued that time is short and we should hurry. Chile was also mentioned quite frequently, being used first as the main reference in the pension model, which was almost entirely private ${ }^{12}$. In all articles in which the country was mentioned, there was the idea that Brazil should copy its pension system ${ }^{13}$. After the 2008 crisis, pension funds and the countries that were more dependent on them began to be used less frequently as good references for a new model for the Brazilian pension system.

Based on the proposal of evaluation analysis (BARDIN, 1979), we identified the direction of the messages, which, in this case, is the view of old age and the elderly depicted in the corpus assessed. Most of the materials bring a purely negative or ambivalent view of old age. In a more detailed level of analysis, these concepts of old age and the elderly were classified into 45 topics. The main notions of old age are linked to a financial conception of the individual, being seen as a source of misery, expenses or resources, according to the

10. Instituto Nacional do Seguro Social (INSS) is the Brazilian National Institute for Social Security.

11. Instituto Brasileiro de Geografia e Estatística (IBGE) is the Public Brazilian Institute of Geography and Statistics.

12. Chilean State offers what the magazine called as a minimum guarantee for survival.

13. As an example, we highlight an article called $O$ que é mesmo que o Chile tem? (What does Chile have?) (CHAIM, 1995), in which all arguments used over the years of analysis were synthesized. 
individual's ability to save for retirement. The idea that was mentioned the most was the need to plan for old age, always highlighting financial planning with other issues involved or not. In the next subsection, the main categories found in the articles assessed are described.

\subsection{THE CATEGORICAL CONTENT ANALYSIS}

Seeking to make explicit the most important notions rooted in the conceptions of old age diffused by the magazine, the material was also assessed using a categorical content analysis. The categorization allows us to give visibility to the unity behind the publications, which may not be clear to the ordinary reader, considering they may not be paying attention to that and not looking at the content in a longitudinal way. Therefore, besides those categories underlying the readers' own notions of the elderly and old age, they may not know the other categories. The four categories found are presented below.

\subsubsection{Planning for retirement}

One of the main issues addressed in these articles was the importance of planning for retirement, mainly financially. Pension schemes as an individual and private product were valued rather than the public system. Most of the articles presented the Brazilian social security program as broken, with pessimistic predictions concerning its future due to factors such as poor management, population aging and unsuitable rules. Moreover, they endorsed proposals of social security reforms, such as reviewing the minimum age for retirement, the full pensions of public workers and military personnel, and the exchange of the repartition or distribution system ${ }^{14}$ through the capitalization one ${ }^{15}$.

Simultaneously, a culture of financial investment and savings was promoted. In the 1990s, the most frequently cited product for economic stability in retirement was the private pension scheme. From 2007 on, there was greater focus on stock investment, including articles highlighting a decrease in the profitability of pension funds in several countries. Furthermore, the articles supported that the pension funds should be able to increase investment in the stock market and each investor could define the level of risk they were willing to take ${ }^{16}$.

Besides, the magazine articles encouraged a behavior in the personal life of the business executives similar to their professional one. Therefore, they were expected to apply the industrial and market logics (BOLTANSKI; THÉVENOT, 2006) in their daily lives. In this sense, the meanings of old age and retirement planning are linked to the prevailing business models. The ideas of good investments followed the increasingly aggressive goals of corporate executives in companies.

14. Portuguese: Sistema de repartição or sistema de distribuição.

15. Portuguese: Sistema de capitalização.

16. There are rules that define the percentages that pension funds and schemes are allowed to invest in more risky markets. 
Proposition 1a: There was an intention to extend the moralities that organize the business executives' lives, which would be the industrial and the market moralities, to the everyday life, based, at first, on a domestic morality.

The articles linked this idea to old age by means of a predominantly economic conception of retirement planning.

Proposition 1b: The overlap between the business executives' way of life and their domestic lives has a bias in a way that the ideal types of investment with pension purpose are increasingly individual and focused on a greater potential for profitability, but also posing higher risks.

\subsubsection{Rationalized life and financial approach to old age}

The second category consists of an increasing promotion of a rationalized life cycle and style. The articles draw on the model of the traditional family and delineate stages of life by means of the chronological age, such as the age of going to college, entering the labor market, and so on, until the age of finally retiring.

The arguments are built around five types of old age: two that are considered suitable, two that would result from a lack of planning and one presented in an ambiguous manner. The elderly is classified as retirees who are still working and retirees who do not work. Those who must work to supplement their income are seen in a negative way, and those who are working in something new, related to their wishes, are seen positively. Among those who do not work, there are old people who depend financially on others or who had to lower their standard of living, presented as a burden or as a sad model of old age, and those who live for leisure, who would be experiencing a happy old age. Moreover, there are old people who would not retire at all, who are business executives that do not want to retire because of the centrality of their job in their lives. They are sometimes exalted and sometimes depreciated.

The centrality of work in life (POLANYI, 1944; DE DECCA, 1982) is enhanced not only by promoting the business executives who do not want to retire, but also by articles that address the difficulties related to retiring, such as the loss of identity and idleness. Then, preparing for retirement would require planning for a new phase of life, due to financial aspects and also because life is labor centered, and when one stops working, they may experience existential problems.

The idea presented in proposition $1 \mathrm{a}$, about the intertwining of the domestic and professional life, is also relevant to understand the links between the rationalization of life and old age.

Proposition 2a: The moralities that organize the business executives' lives, which are highly focused on financial and planning issues, are 
reflected in proposals for the delimitation of life stages, rationalizing and standardizing them, and in a financial emphasis to old age.

Proposition 2b: Looking like descriptions, models of successful business executives who have labor centered lives are, in fact, a prescription for successful careers. This way of life, described as natural, actually imposes an ideal way of life that would enable success in the business life and an autonomous and peaceful old age, limiting the behavior of business executives.

\subsubsection{Population aging and its micro and macroeconomic impacts}

This third category takes population aging mostly as a problem that might cause macro and microeconomic impacts. Regarding macroeconomics, on the one hand, in Brazil, the period since the 1970s has been seen as an opportunity for growth, related to the increase in the proportion of the so-called active population (individuals aged between 14 and 65 years) which might increase productivity and the saving levels in the country, since the increase in life expectancy might encourage people to save for their future. On the other hand, there was a concern about potential problems with increasing longevity, mainly related to expenses related to social security and health (or illnesses), a drop-in saving levels, lack of young labor force and lack of opportunities for the elderly in the labor market.

Proposition 3a: Discussions about demography promote the idea that age is only marked by chronological time. Therefore, changes in age pyramids and life expectancy would be sufficient to delimitate a process of population aging.

Proposition 3b: Discussions about public expenses due to the so-called population aging support the views that the elderly are less active, productive and are sick, and that there is an intergenerational dispute for resources.

In relation to microeconomics, few articles pointed to the existence of new niches and market segments that emerge due to the increase in the number of old people, such as leisure, tourism, courses for the third age, the pharmaceutical industry, housing and physical activities. There are also the aforementioned private pension schemes and labor markets, addressed in more detail in the next subsection, about generational issues. This sensitivity regarding the possibilities of offering products and services for the elderly is fomented appealing to the idea that the elderly holds an important amount of financial resources. In turn, it excludes older people from less privileged backgrounds, who tend to be a source of misery or expense for the State and their families.

Proposition 3c: The niches and market segments highlighted in the articles ignore the multiplicity of lifestyles of the elderly, focusing on 
high-level male business executives, belonging to white families. Thus, on the one hand, these individuals are socially included via the market while, on the other hand, the articles reiterate the social exclusion of individuals who do not fit this standard.

\subsubsection{Generational demarcation and disputes in organizations}

The fourth category describes generational issues. A broad topic is business succession, which works differently in family organizations and companies with more professional management. In family businesses, the entrepreneur, often the founder, mainly presented as initially fighting against leaving the company, ends up yielding to the pressure to retire. It is related to the influential idea that knowing the time to leave is critical to the company's competitiveness. In addition, it also promotes the idea that the heir will be bolder and bring new concepts and knowledge that will renew the company. In turn, the entrepreneur's experience is associated with a level of competence that is superior to the ability of the heir, who would not have the same practical knowledge, the caution necessary to be part of the managerial elites and perhaps not the same business acumen. There are several articles about the disputes over the division of a company among family members and about who would be more appropriate for succession. Mainly in financialized companies, there are also disputes around the entrepreneur and other family members being part of the board of directors and the managerial team or not.

Proposition 4a: The process of hereditary succession is influenced by domestic values and family disputes. For the businessman, losing hegemony in the company also means losing hegemony in the family. Thus, he ${ }^{17}$ tends to struggle to remain in his position for as long as he can. When it is no longer possible, he wants the one who will take over his position to be someone he identifies himself with, someone who he can influence and someone who he considers a good manager.

In the case of companies in which business succession is professionalized, one important aspect is mandatory retirement. According to the articles, the intention of this practice is to renew and to motivate young employees, preventing the older ones from obstructing the career growth of the younger ones.

Proposition 4b: The process of succession in professionalized companies is marked by inter- and intra-generational disputes.

The promotion of private pension schemes also draws on this issue. If retirement is related to financial uncertainty, there will be greater resistance to it. The private pension plans and the pension funds would be the security required to motivate retirement. The

17. I use the pronoun "he" because the articles always cited men as the business executives and women were cited mostly as their wives. 
articles also presented advantages and disadvantages of having old or young individuals in companies. Young executives are relatively common figures on magazine pages, often taken as innovative and up-to-date, especially in relation to training.

Proposition 4c: Generations are taken as homogeneous, and, thus, individuals of a given generation are expected to behave similarly to each other. It is also often assumed that individuals of a certain age (usually around 40 years old) are unable to adapt to change.

However, there are discussions about the boss being younger than the subordinate and about people working in teams in which individuals are of very different ages. The features of the younger and older business executives are taken in a similar way to that presented previously. There are few articles that consider intergenerational interaction as positive.

\section{FINAL REMARKS}

The aim of the paper was to analyze the conceptions of old age that have been diffused by the Brazilian business press in the context of the increasing longevity of the population and of the emergence of the financialized economy in the country. Two notions were key for the assessment conducted. First, old age was taken as a social and historical construction, rather than a biological instance. Second, we departed from the understanding that the economic field is pervasive, shaping and being shaped by social and cultural aspects and power relations.

In general, in the content analysis carried out, old age was portrayed as a privileged moment of achieving the dreams postponed throughout life. This emerging notion clashes with more negative ones, often related to retirement. There is a struggle between the ideas of old age as a source of resources and as a source of misery and expenses, which creates barriers to its re-signification. The economic logic is often dominant, and the articles are often based on the idea that one should plan his or her future aiming not to reduce the consumption power in old age. The articles alternate between a micro level, in which the individuals are responsible for planning their old age and taking care of themselves when they are older, and a more macro level, concerning the State and demographic changes. An individualized view of old age is promoted to the detriment of proposals that generate intergenerational solidarity, such as in the case of pension schemes, in which the capitalization system is reinforced, rather than the distributive one.

The dominant notions about old age influence and are influenced by pension scheme markets and other financial investments with retirement purposes, as the economic power has been used as a key factor to reframe old age. These diffused sensibilities are highly convergent with the interests of financial markets, which may be related to the fact that Exame focuses on business executives and its journalists and editor teams, and their main references, are somehow related to the financial market. The endeavor of the magazine to encourage their readers to save and invest for old age indicates the huge capacity of the economy to shape the meaning of life in contemporary societies and, more specifically, the influence of finance in our culture and the everyday life. 
The results of this study are in line with the contemporary theme of financialization of the daily life, showing how this phenomenon has operated on a specific issue and that even a matter considered so natural as old age is subject to the influence of the representations diffused by the economic field. It is important to stress that we did not access reality directly, but by means of the business press cultural production, which is not the economic world itself, but mainly a representation of it. Despite having great space and strength in the economic field, media actors interpret it based on their own cognitive conventions and in the context of a specific game, and one should not consider their production as something that automatically turns into practice. Actually, the assessment presented opens up an extensive research agenda and may be used as a guideline for further investigation. Thus, it may be promising to understand the relations between the media discourse and other more practical issues, such as the historical shifts in investments for retirement, the paths taken by retired executives and company programs for preparing employees for retirement.

\section{ACKNOWLEDGEMENTS}

Thank Roberto Grün for the supervision of research. I am also grateful to Coordenação de Aperfeiçoamento de Pessoal de Nível Superior (CAPES) and to Fundação de Amparo à Pesquisa do Estado de São Paulo (FAPESP), process 2014 / 11157-0, for financial support.

\section{REFERENCES}

ARIÈS, P. História social da criança e da família. 1978.

BARDIN, L. Análise de conteúdo. 1979.

BEAUVOIR, S. L. E. M. B. La vieillesse. Gallimard, 1970.

BELL, J. In search of a discourse on aging: The elderly on television. The Gerontologist, $v$. 32, n. 3, p. 305-311, 1992.

BLANPAIN, N. L'espérance de vie s' accroît, les inégalités sociales face à la mort demeurent. Insee Première, n. 1372, 2011.

BOLTANSKI, L.; THÉVENOT, L. On justification: Economies of worth. Princeton University Press, 2006.

BOURDIEU, P. Practical reason: On the theory of action. Stanford University Press, 1998. . Le champ économique. 1997.

. The market of symbolic goods. Poetics, v. 14, n. 1-2, p. 13-44, 1985.

. The economics of linguistic exchanges. Social science information, v. 16, n. 6, p. 645-668, 1977.

BOURDIEU, P.; JOHNSON, R. The field of cultural production: Essays on art and literature. Columbia University Press, 1993.

BOURDIEU, P.; WACQUANT, L. An Invitation to reflexive sociology. Cambridge, Polity Press, 1992. 
BROWN, A.; KNIGHT, T. Shifts in media images of women appearance and social status from 1960 to 2010: A content analysis of beauty advertisements in two Australian magazines. Journal of aging studies, v. 35, p. 74-83, 2015.

CAMARANO, A. A.; PASINATO, M. T. Introdução. In: CAMARANO, A. A (org.). Os novos idosos brasileiros. Muito além dos 60? Rio de Janeiro: IPEA, p. 1-22, 2004.

CARRUTHERS, B.G.; KIM, J.C. The sociology of finance. Annu. Rev. Sociol. v. 37, p. 239259, 2011.

CHAMPAGNE, P. Le journalisme à l'économie. ARSS, n. 131-132, 2000.

CLARK, L. H.; BENNETT, E. V.; LIU, C. Aging and masculinity: Portrayals in men's magazines. Journal of aging studies, v. 31, p. 26-33, 2014.

CLARK, R.; KREPS, J. E.; SPENGLER, J. Economics of aging. A survey. Journal of Economic Literature, v. 16, p. 919-962, 1978.

DAVIS, G. F. After the ownership society: Another world is possible. In: DAVIS, G. F. Markets on Trial: The Economic Sociology of the US Financial Crisis. Part B. Emerald Group Publishing Limited, 2010, p. 331-356.

DAVIS, G. F. Managed by the markets: How finance re-shaped America. Oxford University Press, 2009.

DAVIS, G. F.; KIM, S. Financialization of the economy. Sociology, v. 41, n. 1, 2015.

DEBERT, G. G. O velho na propaganda. Cadernos Pagu, v. 21, p. 133-155, 2003.

. A invenção da terceira idade e a rearticulação de formas de consumo e demandas políticas. Rev. bras. Ci. Soc., v. 12, n. 34, 1997.

DE DECCA, E. 0 nascimento das fábricas. São Paulo: Brasiliense, 1982.

DUMONS, B.; POLLET, G. L'État et les retraites: Genèse d'une politique. Belin, 1994.

ERTURK, I. et al. The Democratisation of Finance? Promises, Outcomes and Conditions, Review of International Political Economy, v. 14, p. 553-575, 2007.

EXAME. Sua excelência, o nosso leitor. Revista Exame, v. 462, p. 114-116, 1990.

FLICK, U. Uma introdução à pesquisa qualitativa. v. 2. Porto Alegre: Bookman, 2004.

FLIGSTEIN, N. The transformation of corporate control. Harvard University Press, 1993.

GADSON, A. D. Neither hearth nor home: The (un)making of elder care responsibility. Journal of Aging Studies, 2003, v. 17, n. 1, p. 17-29.

GOLDANI, A. M. Relações intergeracionais e reconstrução do Estado de bem-estar. Por que se deve repensar essa relação para o Brasil? In: CAMARANO, A. A (org.). Os novos idosos brasileiros. Muito além dos 60? Rio de Janeiro: IPEA, 2004. p. 211-252.

GREENBERG, B. S.; KORZENNY, F.; ATKIN, C. K. The Portrayal of the Aging Trends on Commercial Television. Research on Aging, v. 1, n. 3, p. 319-334, 1979.

GRÜN, R. Modelos de empresa, modelos de mundo: sobre algumas características culturais da nova ordem econômica e da resistência a ela. Revista Brasileira de Ciências Sociais, v. 14, n. 41, p. 121-140, 1999. 
HALBWACHS, M. La statistique em sociologie. In: HALBWACHS, M. La statistique, ses applications, lês problèmes qu'elle soulève. Paris: Les Presses Universitaires de France, 1944, p. 113-134.

IPSOS MARPLAN. Pesquisa de mercado Exame. Revista Exame, 2007.

INSTITUTO VERIFICADOR DE CIRCULAÇÃO (IVC). Institutional Web Page. IVC. 2014. Available from: http://www.ivc.org.br/ijeweb/scripts/ijeweb.cgi/actfrmresumo?c=766. Accessed 22 May 2015.

JAMIESON, K. H.; CAPPELLA, J. N. Echo chamber: Rush Limbaugh and the conservative media establishment. Oxford University Pres, 2008.

KOHLBACHER, F.; HERSTATT, C. The silver market phenomenon: marketing and innovation in the aging society. 2nd ed., Germany: Springer, 2011, p. 279-294.

KRIPPNER, G. R. The financialization of the American economy. Socio-economic review, v. 3, n. 2, p. 173-208, 2005.

LASLETT, P. The emergence of the third age. Ageing and society, v. 7, n. 2, p. 133-160, 1987.

LEBARON, G. The political economy of the household: Neoliberal restructuring, enclosures, and daily life. Review of International Political Economy, v. 17, n. 5, p. 889-912, 2010.

LEIBING, A. The old lady from Ipanema: changing notions of old age in Brazil. Journal of Aging Studies, v. 19, n. 1, p. 15-31, 2005.

LEITE, N. Mídia expõe imagem negativa de idosos. Revista Eletrônica Com Ciência, 2002. Available from: http://www.comciencia.br/dossies-172/reportagens/envelhecimento/texto/ env09.htm. Accessed 19 dec. 2017.

LENOIR, R. Objet sociologique et probleme social. In: CHAMPAGNE, P. et al. Initiation à la pratique sociologique, 1999.

MACNICOL, J. Neoliberalising Old Age. Cambridge, UK: Cambridge University Press, 2015, $254 \mathrm{p}$.

MANNHEIM, K. Das Problem der Generationen. Kölner Vierteljahrshefte für Soziologie, v. 7, 1928.

MAUGER, G. As novas formas simbólicas de dominação e desigualdade social. Projeto Pesquisador Visitante. Processo 2013/02187-0. De autoria de Jardim, M. C. Faculdade de Ciências e Letras de Araraquara, Araraquara. 2013.

MARTIN, R. Financialization of daily life. Temple University Press, 2002.

MASCARO, S. D. A. As imagens dos velhos e da velhice nas páginas do jornal "O Estado de S. Paulo" (1988-1991). 1993. Tese (Doutorado) - ECA/USP. 1993.

MEINERS, N. Economics of ageing: research area and perspectives. Quality in Ageing and Older Adults, v. 15, n. 2, p. 63-75, 2014.

MÍDIA COMPANY. Mídia kit. 2013. Available from: http://www.midiacompany.com.br/portfolio.html. Accessed 29 Jan. 2016. 
MOLLS, R. Introduction à la demographie des villes d'Europe de XIV au XVIII siècles. Speculum, Cambridge, v. 34, n. 4, p. 670-672, 1959.

MURATA, $H$. The Business of Aging: Ten Successful Strategies for a Diverse Market. In: KOHLBACHER, F.; HERSTATT, C. (eds) The Silver Market Phenomenon. Springer, Berlin, Heidelberg, 2008.

NERI, A. L. Atitudes e crenças sobre velhice: análise de conteúdo de textos do jornal 0 Estado de São Paulo publicados entre 1995 e 2002. In: SIMSON, O.R. de M.; NERI, A.L.; CACHIONI, M. As Múltiplas Faces da Velhice no Brasil. Brasil: Alínea Editora, 2006.

PELLISSIER, J. Com que idade nos tornamos velhos? Le Monde Diplomatique Brasil, 2013. PINTO, R.; GRAWITZ, M. Méthodes des sciences sociales. Dalloz, 1969.

PIRES, A. Velhos em revista: envelhecimento e velhice nas páginas de Claudia e Playboy (anos 80 e 90). 1998. Dissertação (Mestrado) - IFCH/Unicamp. 1998. Available from: http://repositorio.unicamp.br/jspui/handle/REPOSIP/282008. Accessed 14 Jul. 2019.

POLANYI, K. The great transformation: The political and economic origins of our time. Beacon Press, 1944.

SILVEIRA, M. H.; LAURENTI, R. Os eventos vitais: aspectos de seus registros e inter-relação da legislação vigente com as estatísticas de saúde. Revista de Saúde Pública, v. 7, n. 1, p. 37-50, 1973.

TREMPÉ, R. Les mineurs de Carmaux: 1848-1914. v. 1. Les éditions ouvrières, 1971.

VOSS, C.; TSIKRIKTIS, N.; FROHLICH, M. Case research in operations management. International Journal of Operations \& Production Management, v. 22, n. 2, p. 195-219, 2002.

VAN DER ZWAN, N. Making sense of financialization. Socio-economic review, v. 12, n. 1 , p. 99-129, 2014.

WACQUANT, L. Mapping the artistic field. Sociologia, n. 48, 2005.

WHO. WORLD HEALTH ORGANIZATION. Global health indicators. Life expectancy and mortality. In: WHO. WORLD HEALTH ORGANIZATION. World Health Statistics 2014. 2014. Available from: http://apps.who.int/iris/bitstream/10665/112738/1/9789240692671_eng. pdf. Accessed 23 Jul. 2015.

WHO. WORLD HEALTH ORGANIZATION. Active Ageing. The Concept and Rationale. 2002.

WILLIAMSON, J. B. Privatizing public pension systems. Lessons from Latin America. Journal of Aging Studies, v. 15, p. 285-302, 2001.

Data de Submissão: 17/07/2017.

Data de Aprovação: 16/08/2018. 